can be readily pumped out from the cable and replaced by fresh gas capable of restoring the dry atmosphere required to maintain a high insulation resistance. In the exchange itself, the type of apparatus employed is designed to permit calls to be completed on demand, that is, whilst the calling subscriber is held on the line. Timing the duration of calls is a problem which has received special attention. In the trunk exchanges, all calls are timed automatically; this obviates any error due to the human element, and, as the calls are expensive, this is very desirable. The particulars from the timerecording instruments, together with the called and calling subscribers' numbers, are entered on a ticket by the operator and circulated to a central pricing position. The circulation is effected by pneumatic tubes. The power for the exchange is derived from secondary cells of large capacity. A voltage of 50 is used for normal speech and apparatus purposes, but the signalling lamps on the switchboard are worked at six volts from an alternating current source.

\section{Grading of Teak Squares}

Wrтн the hearty co-operation of business firms, the Forest Research Institute at Dehra Dun has published a small pocket monograph entitled "Rules for the Grading of Teak Squares", prepared by L. N. Seaman, officer in charge, Timber Testing Station, and V. D. Limaye. In a preface, Mr. C. G. Trevor, Inspector General of Forests, states that the work was undertaken at the request of the Chief Conservator of Forests, Burma, and the Indian Railways, and the Burma forest officers were deputed to the saw mills of the five chief teak firms to observe and write down in tabular form all the defects in each teak square passed by the respective firms as belonging to different existing grades. The data so obtained were dispatched to Dehra Dun for analysis, and preliminary draft rules were drawn up by $\mathrm{Mr}$. Seaman and his staff. These rules were discussed at a meeting held in Rangoon between the parties interested, and a trial was made of them. As a result of experience gained, the rules were re-written by Mr. Limaye (Mr. Seaman having left India on retirement) and are now published in the present handy form. The rules express, in so many words, the actual practice that is followed in the trade in the grading of teak squares. The rules have been accepted by the teak lessees of Burma and the timber adviser to the Railway Board and the Arroy. The rules are equally applicable to mill-sawn squares from Siam and other countries, and it is suggested that in future they will always be used for the buying and selling of teak squares.

\section{Design in Industry}

Ar the opening meeting of the new session of the Royal Society of Arts on November 4, the chairman of the Council, Sir Henry McMahon, announced the institution of a new distinction of D.I. (Designer for Industry) for designers for industry who have attained eminence in creative design. The distinction is limited in the first instance to ten and the number of holders of it at any one time will not exceed thirty. The essence of the scheme is to encourage the improvement of industrial design by enhancing the status of the designer in the public regard, and thereby arousing a more general recognition of the importance of industrial art. This latest step is in continuance of the Society's efforts in this field from the eighteenth century onward, and is a natural development of the annual competition of industrial designs initiated in 1923 and of the Exhibition of British Art in Industry organized at Burlington House last year in co-opera. tion with the Royal Academy. The very success of the Exhibition, which stimulated a widespread movement advocating the cause of art in industry, emphasized the fact that no recognition or distinetion was heretofore available for designers, who through their great work for industry are deserving of wide public recognition of their valuable services to their country. This gap, it is hoped, will be filled by the new distinction.

\section{The Geographical Magazine}

Tre completion of the second year of the Geographical Magazine directs attention to the value of its articles and the excellence of its illustrations, the photogravure and coloured plates in particular reaching a high standard. Among articles in the December issue is one by Dr. R. Zeller on the "Development of Alpinism in Switzerland" which is illustrated by a large number of old prints. In view of the modern vogue of alpinism, which the writer defines as an interest in high mountains and their exploration, it is worth noting that at least until the eighteenth century the Alps repelled travellers. The influence of two writers, von Haller and Rousseau, did much to direct attention to the Alps, but with a few exceptions there was little real mountaineering until Paccard and Balmat climbed Mont Blanc in 1786. Maps did not become available until the nineteenth century, and from the middle of that century onwards accurate maps and guide books were great stimuli to active alpinism, while the twentieth contury may be said to have seen its popularization.

\section{Demographic Statistics}

According to statistics recently published in Germany, the average duration of human life in most countries was about fifteen years longer in 1921 than in 1871. In 1880 in Germany, 261 out of 10,000 inhabitants died as compared with 212 in 1900 and 111 in 1930. During the same periods there were 205, 182 and 114 deaths in England, and 198, 176 and 113 in the United States. In Hungary the decline of mortality was most pronounced, there being 386 deaths per 10,000 inhabitants in 1880 and only 155 in 1930. During the same period of half a century, the percentage fall of mortality in different countries was as follows: Germany, 54.8; England, 44.4; France, 22.6 ; Italy, 41.7 ; Switzerland, 51.8; Sweden, $39 \cdot 7$; United States, $40 \cdot 4$; and Australia, 46.9 (Bruxelles Méd., October 25). 